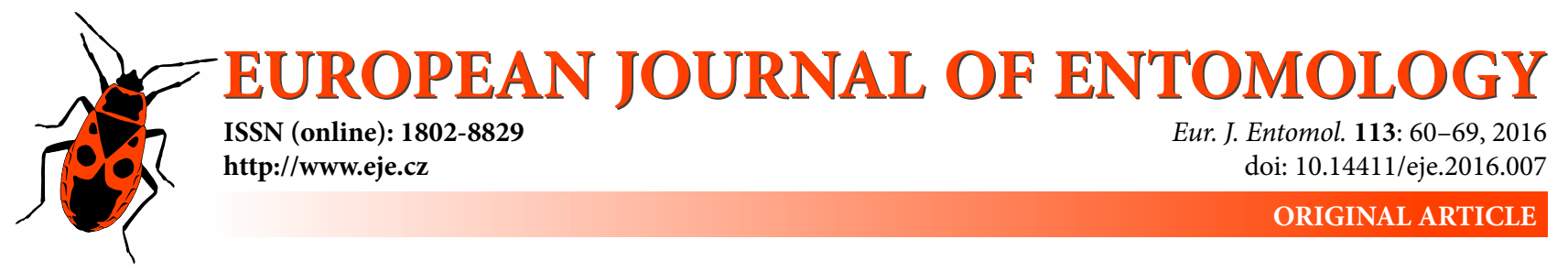

\title{
Effects of habitat and landscape features on grassland Orthoptera on floodplains in the lower reaches of the Tisza River Basin
}

\author{
AtTILA TORMA ${ }^{1}$ and MıkLós BOZSÓ ${ }^{2}$ \\ ${ }^{1}$ Department of Ecology, University of Szeged, Közép Fasor 52, Szeged H-6726, Hungary; e-mail: torma_a@yahoo.com \\ ${ }^{2}$ Plant Health and Molecular Biology Laboratory, Directorate of Plant Protection, Soil Conservation and Agri-environment, \\ National Food Chain Safety Office, Budaörsi u. 141-145, Budapest H-1118, Hungary; e-mail: mikitv.bozs@gmail.com
}

Key words. Orthoptera, Caelifera, Ensifera, dispersal, diversity, flooding, niche breadth, reproductive potential

\begin{abstract}
The Tisza River Basin is an important area as it is a green corridor in which there are highly endangered habitats and a high level of biodiversity. The patterns in the species richness of invertebrates and the environmental conditions affecting these patterns are poorly studied in the grassy habitats in the lower reaches of the Tisza River Basin. The present study focuses on the effects of flooding, habitat and landscape features on the species richness of orthopterans at 24 grassland sites in two different landscapes. The relations between the explanatory variables and the pattern of diversity of orthopterans with different life-history traits were studied, using ordination and Generalized Linear Mixed Models. Although the influential factors for the different trait groups differed, we suggest that landscape features are the most important in shaping orthopteran assemblages, whereas habitat characteristics and flooding have comparatively little effect. Habitat characteristics affected only the non-xerophilous and Ensifera species and only the species richness of non-xerophilous orthopterans in flooded and non-flooded sites differed. We emphasize that even in countries where there are still considerable areas of high value natural grasslands, such as Hungary, non-protected meadows, linear grassy habitats (dikes, ditch banks, road verges, etc.) need more attention and should be given higher priority in the conservation of invertebrates.
\end{abstract}

\section{INTRODUCTION}

In their natural state, riverine landscapes are characterized by mosaics of various habitat patches. Due to their high heterogeneity and connectivity (Naiman et al., 2005), they can support a diverse flora and fauna (Gregory et al., 1991; Zwick, 1992; Ward et al., 1999). However, many European rivers are restricted to narrow riverbeds bordered by dikes and the majority of floodplain habitats have been transformed into agricultural land (Tockner et al., 2009), causing a severe decline in biodiversity (Godreau et al., 1999).

The River Tisza is the largest tributary of the Danube and its catchment includes most of the Carpathian Mountains covering approximately $157,000 \mathrm{~km}^{2}$ (Sommerwerk et al., 2009). The regulation of the Tisza in the 19th century caused profound changes; a considerable amount of the former floodplain has since never been flooded. However, on this non-flooded part of the former floodplain (so-called "historical floodplain") there were several high value habitats, i.e. pastures, woody pastures and hay-meadows, in this extensively used mosaic landscape until the 1950s (Deák, 2007; Sendzimir et al., 2008). During the socialist era, intensification of agriculture resulted in a decrease in the area of these grasslands (Deák, 2007). Nowadays, the remaining grasslands are surrounded by a highly modified landscape consisting of arable fields and forest plantations, often of non-native trees. Despite these changes, the Tisza River Basin (TRB) still includes highly endangered habitats, which are important ecological areas and green corridors (L. Gallé et al., 1995; Rádai, 1995) with a high level of biodiversity (Sommerwerk et al., 2009). The invertebrate fauna in the TRB is well-documented (see e.g. L. Gallé, 2005, 2008), but there are only a few studies on some taxa, e.g. spiders (Araneae) (R. Gallé et al., 2011) and true bugs (Heteroptera) (Torma \& Császár, 2013), which indicate the environmental conditions that are likely to influence the species richness of grassland arthropods in this human-modified riverine landscape. To the best of our knowledge, patterns in the diversity of assemblages of Orthoptera in relation to their life-history traits and environmental conditions have not been studied in this region.

Orthopteran assemblages are known to depend on different and often interrelated environmental factors. Vegetation has a great influence on many invertebrates, including orthopterans (Batáry et al., 2007; Poniatowski \& Fartmann $2008,2010)$. Vegetation is related to soil and microclimate conditions, which are also important for orthopterans (Willott \& Hassall, 1998; Gardiner \& Dover, 2008). In ripar- 
ian landscapes, flooding and land use pressure have a pronounced influence in shaping assemblages of Orthoptera (Dziock et al., 2011). The majority of species of Orthoptera are associated with open grassy habitats; therefore, for these species the amount of grassland in a landscape is important (Marini et al., 2008; Badenhausser \& Cordeau, 2012). The "habitat amount hypothesis" (Fahrig, 2013) postulates that patch size and patch isolation effects are both due mainly to the sample area effect, thus patch size and isolation can be replaced with a single variable, the amount of habitat.

In order to determine the main factors affecting orthopterans, we tested the effects of (1) habitat characteristics (soil moisture and vegetation structure and diversity), (2) landscape features (amount of grassland habitat, landscape structure) and (3) flooding (flooded vs. non-flooded sites) on the species composition and richness of assemblages of Orthoptera. The effect of landscape composition on assemblages of Orthoptera is often scale-dependent (e.g. Marini et al., 2009a), thus we also aimed to determine the appropriate spatial scale for assessing the amount of grassland habitat. As species with different life history traits often need different environmental conditions, the effects on species richness of various life-history traits were tested separately.

\section{MATERIAL AND METHODS}

\section{Study sites and sampling design}

Assemblages of Orthoptera were studied at 24 sites in two different landscapes. The landscapes were located on the same side of the river in Csongrád County, Hungary, and were selected based on intensity of land use and landscape structure. The heterogeneous landscape (HET) was situated near the town of Szeged (approx. $46^{\circ} 17^{\prime} 34^{\prime \prime} \mathrm{N}, \mathrm{E} 20^{\circ} 12^{\prime} 45^{\prime \prime} \mathrm{E}$ ) and it consisted of a mosaic of various habitats. The percentage of the area covered by intensively managed arable fields was high $(58.3 \pm 3.4 \%$, mean $\pm \mathrm{SE}$ within a radius of $500 \mathrm{~m}$ around the sites). Small patches of meadows with trees and abandoned fields were embedded in the matrix of arable fields. Numerous trees and bushes also occurred along road verges, but continuous forest occurred only near the river. The percentage of the area covered by forest habitats, including single trees and bushes, was $18.6 \pm 5.6 \%$.

The homogeneous landscape (HOM) was situated approximately $30 \mathrm{~km}$ north of Szeged (approx.: $46^{\circ} 27^{\prime} 27^{\prime \prime} \mathrm{N}, 20^{\circ} 9^{\prime} 26^{\prime \prime} \mathrm{E}$ ). The intensity of agricultural activities in this area was moderate (the percentage covered by arable fields was $16.1 \pm 1.9 \%$ ) and the percentage of the area covered with semi-natural grasslands and forests was high. The percentage covered by forest was higher $(30.0 \pm 3.3 \%)$ than in HET due to the oak and poplar forests that bordered and partly divided the relatively continuous grassland area into two parts.

Among the various grassy habitats on the historical floodplain of the Tisza, only those that occurred in both landscapes were selected for this study i.e., sand steppe and alkaline meadows in the non-flooded part of the historical floodplain, dike-slope meadows (strip-like meadows on the slopes of the dikes) and floodplain meadows. Each of these habitats occurred at the three sites sampled, giving a total of 24 sites in the two landscapes. The distance between sites was approximately $500 \mathrm{~m}$, except in the case of floodplain meadows. Orthopterans were collected by sweep netting, which is a widely used technique for sampling these insects (e.g. Bauer \& Kenyeres, 2007; Torma et al., 2014). At each site, sweep netting was carried out along three, $50 \mathrm{~m}$ long, fixed transects in 2009. To avoid periods of flooding, sweep netting was carried out in summer. The first samples (30 May-2 June) were collected before mowing and the second samples (22-24 July) when the vegetation started to regrow after mowing. For the data analyses, the sweep netting samples were pooled separately for transects and periods, resulting in a total of 24 statistical samples (one sample per site).

\section{Assessments of explanatory variables}

Habitat and landscape features were assessed at each site (Appendix 1). Habitat characteristics included features of the vegetation and soil water content. The vegetation was sampled in three, $1 \times 1 \mathrm{~m}$ quadrats along each transect. Mean data for the quadrats were used to define variables at the sites sampled. To characterize the structure of vegetation, the average height of the vegetation, the total cover of vegetation at 10 and $40 \mathrm{~cm}$ above the ground and cover of litter were recorded. To characterize the richness of vegetation, the total number of species of plants and of only the dicotyledonous plants were recorded in the quadrats. Soil samples were taken from the top 10 centimetres close by the coenological quadrats. The percentage of gravimetric water in soil samples was measured.

To assess the amount of habitat we measured the percentage of the area covered with grassland in a radius of 100, 250, 500 and $750 \mathrm{~m}$ around each site using ArcView 3.11 GIS software.

\section{Life-history traits}

Dispersal ability, niche breadth and reproductive potential were the traits considered, because they are hypothesized to be key determinants of species persistence (Kotiaho et al., 2005). As a measure of dispersal ability, the mobility index (Reinhardt et al., 2005) was used. However, mobility is not a constant trait for orthopterans; it may differ between and within populations (e.g. Endo, 2006; Poniatowski \& Fartmann, 2009). To reduce the effect of this potential variability, broad mobility classes: sedentary, intermediate disperser and mobile species, were identified. Further, intermediate dispersers were excluded from the analyses, as they are often the species whose classification is uncertain (cf. Marini et al., 2009a; 2012). The mean number of ovarioles is a rough measure of the reproductive potential of females (Reinhardt et al., 2005) and is generally coded into three categories: low $(<10)$, intermediate (11-25) and high (>25) (cf. Dziock et al., 2011). However, this trait is proportional to body size and the phylogeny of the species (Dziock et al., 2011), and Ensifera species are usually placed in a higher reproductive category than Caelifera (see also our data in Appendix 1). Further, Ensifera species usually produce larger eggs and lay them individually in plants or under tree bark, behaviour which can increase the chance of hydrochory and thus their passive dispersal ability (Dziock et al., 2011). Therefore, Ensifera and Caelifera were used as examples of the differences in reproductive potential and passive dispersal of the species.

Orthoptera clearly differ in their preference for habitats of different humidity, and this trait is often used to group them in relation to their habitat specialization (cf. Fartmann et al., 2012). As most of the collected species preferred dry habitats and the number of hygrophilous species was rather low, we sorted them into two groups: xerophilous and non-xerophilous (hygrophilous and mezophilous) species.

\section{Data analyses}

To evaluate the degree of collinearity, Pearson correlation coefficients were computed between habitat variables (soil water content, vegetation height, the cover of vegetation at 10 and 40 $\mathrm{cm}$ above the ground, cover of litter, plant species richness) prior 
to analyses (Appendix 2). As the variables were highly inter-correlated, a Principal Component Analysis (PCA) was carried out and the scores on the first axis, which explained $85.2 \%$ of the total variance and correlated significantly with each of the assessed habitat variables (Appendix 2), were used as a habitat descriptor (cf. Poniatowski \& Fartmann, 2011; Münsch et al., 2013). The newly created variable represents a gradient from sites with dry soils and uniform vegetation (low values) to sites with moist soils and a high architectural complexity and diversity of vegetation (high values).

Similar to previous studies (e.g. Steffan-Dewenter et al., 2002; Cozzi et al., 2008), as landscape variables quantified at nested spatial scales were obviously highly correlated, we determined the scale which best explained the variation for orthopterans. To evaluate the spatial scale, we used a Generalized Linear Model (GLM, Poisson errors) to describe the relationships between the response and landscape variables (percentage of surrounding area that is grassland) for each radius separately (cf. Marini et al., 2009b).

To analyse the species composition of assemblages of Orthoptera and its relationship with environmental variables, Non-metric Multidimensional Scaling (NMDS, Bray-Curtis dissimilarity) was used and environmental vectors were fitted onto the ordination space. Generalized Linear Mixed Models (GLMM, Poisson errors, maximum likelihood fit) were used to test the effects of explanatory variables and factors on the species richness of the Orthoptera. In the GLMM, the effect of habitats sampled was used as a random effect and the selected explanatory variables (habitat descriptor, amount of grassland) as fixed effects. To test for significances, the effect of landscape (HOM vs. HET) and of flooding (flooded vs. non-flooded sites) were also subjected to GLMM as fixed effects. Automated model selection was carried out, and the effects of different explanatory factors and variables were averaged across the best models with delta $<2$ (Grueber et al., 2011).

All statistical analyses were carried out in an R Statistical Environment (R Development Core Team, 2013). GLMM was performed using the glmer function in lme4 package (Bates et al., 2013); automated model selection was carried out with the dredge function in MuMIn package (Bartoń, 2013). Ordinations were performed in the Vegan package (Oksanen et al., 2013); environmental vectors and factors were fitted onto ordination space using the envfit function.

\section{RESULTS}

\section{Orthopteran assemblages}

Altogether 1529 adult individuals of 16 species of Caelifera and 11 of Ensifera were collected (Appendix 1). In terms of mobility 15 were categorized as mobile, 5 as intermediate dispersers and 7 as sedentary and in terms of habitat preference 16 and 11 of these species were categorized xerophilous and non-xerophilous, respectively. The most abundant species was Euchorthippus declivus (Brisout de Barneville, 1849), which made up 31.92\% of the total number collected. Other abundant species were Chotrhippus dichrous (Eversmann, 1859) (12.10\%), Ch. dorsatus (Zetterstedt, 1821) (11.05\%) and Pezotettix giornae (Rossi, 1794) (10.92\%).

Numerous endangered, critically endangered or protected species such as Gampsocleis glabra (Herbst, 1786), Ruspolia nitidula (Scopoli, 1786), Platycleis vittata (Charpentier, 1825), Acrida hungarica Herbst, 1786 and Epac-

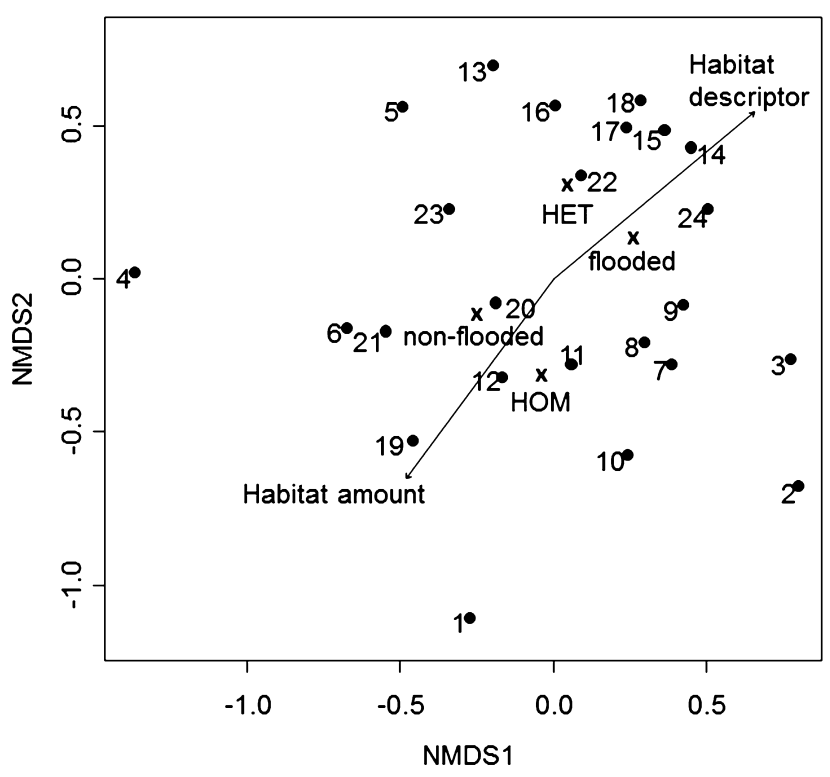

Fig. 1. NMDS ordination (stress: 19.97) showing the natural grouping of sites based on the species composition of Orthoptera. Black circles and numbers indicate the sites sampled in sand steppe meadows (1-3, 22-24), alkaline meadows (4-6, 19-21), floodplain meadows (7-9, 13-15) and dike-slope meadows (10-12, 16-18) in homogeneous (1-12) and heterogeneous (13-24) landscapes, respectively. The environmental variables (habitat descriptor and amount of surrounding grassland) and factors (flooded vs. nonflooded sites, homogenous vs. heterogeneous landscape) were passively fitted onto the ordination diagram. For significances of their effects see Table 1.

romius coerulipes (Ivanov, 1888) were also collected. Although these species need different environmental conditions, e.g. $R$. nitidula is a rare inhabitant of wetlands, $P$. vittata and $G$. glabra prefer xeric, tall grassy vegetation, they were almost all collected in the dike slope habitat. Specimens of $E$. coerulipes were collected only at alkaline sites in the HET landscape.

According to the NMDS, the variation in the composition of the samples was caused mainly by the difference between the two landscapes (Fig. 1, Table 1).

\section{Species richness of orthopteran assemblages}

The Poisson regressions indicated that the total species richness and the richness of species of both Ensifera and Caelifera were associated in a scale-dependent manner with the percentage of grassland in the surroundings (Fig. 2 ). The scale with the largest decrease in residual deviance was $500 \mathrm{~m}$. For sedentary and non-xerophilous species, the scale with the largest decrease in residual deviance was

Table 1. The significances of fitted environmental variables and factors on the NMDS ordination. $P$ values based on 999 permutations.

\begin{tabular}{lcrrrr}
\hline $\begin{array}{l}\text { Environmental } \\
\text { variables }\end{array}$ & & NMDS1 & NMDS2 & $\mathrm{R}^{2}$ & $\mathrm{P}$ \\
\hline Habitat descriptor & & 0.719 & 0.695 & 0.23 & 0.067 \\
\hline Habitat amount & & -0.533 & -0.846 & 0.18 & 0.126 \\
\hline \multirow{2}{*}{ Flooding } & Flooded & 0.151 & 0.138 & \multirow{2}{*}{0.09} & \multirow{2}{*}{0.118} \\
\cline { 2 - 5 } Landscape & Non-flooded & -0.151 & -0.138 & & \\
\hline & Heterogeneous & -0.027 & 0.253 & \multirow{2}{*}{0.15} & \multirow{2}{*}{$0.029 *$} \\
\cline { 2 - 6 } & Homogeneous & 0.027 & -0.253 & & \\
\hline
\end{tabular}




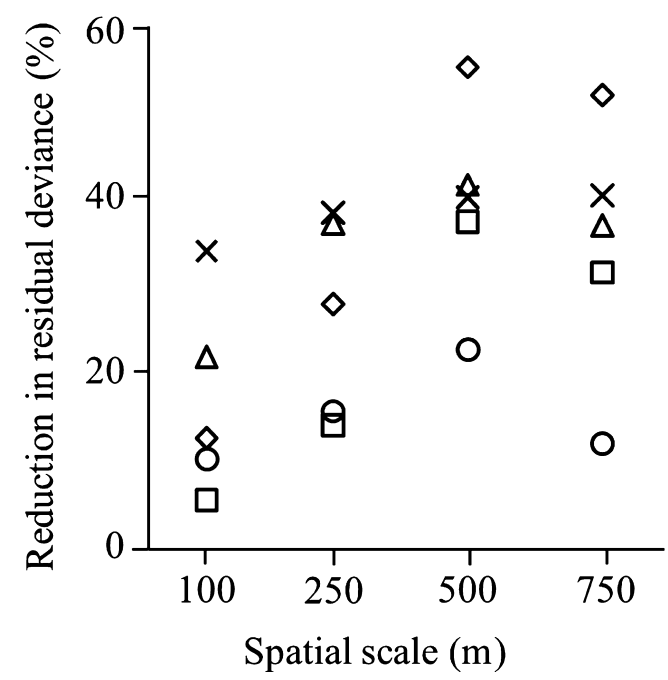

Fig. 2. Scale-dependent effects of the percentage of grassland in the surroundings on the number of all Orthoptera (diamonds), Ensifera (circles), Caelifera (squares), sedentary (triangles) and nonxerophilous (crosses) species. The Poisson regressions between orthopteran species richness and the percentage of grassland in a radius of $100,250,500$ and $750 \mathrm{~m}$ around the sites sampled indicates a decrease in the residual deviance (percentage). In the case of other trait groups, no significant scale-dependent effect of the percentage of grassland was detected.

also $500 \mathrm{~m}$; however, the differences between the different scales were not large.

For all the species collected, the model selection resulted in an average best model that included the effect of landscape, flooding and amount of habitat (Table 2). The species richness decreased significantly with increase in the percentage of grassland in the surroundings $(\mathrm{z}=2.73, \mathrm{P}=$ 0.006) (Fig. 3a); landscape $(\mathrm{z}=1.33, \mathrm{P}=0.184)$ and flooding $(\mathrm{z}=1.28, \mathrm{P}=0.199)$ were not significant.

The average best model for Ensifera (Table 2) included the significant effect of amount of habitat $(\mathrm{z}=2.33, \mathrm{P}=$
0.020) and the habitat descriptor $(\mathrm{z}=1.92, \mathrm{P}=0.049)$ (Figs $3 \mathrm{~b}, \mathrm{e})$.

The average best model explaining the species richness of Caelifera (Table 2) included landscape, flooding, amount of habitat and the habitat descriptor. The effect of landscape was significant ( $\mathrm{z}=2.93, \mathrm{P}=0.003$ ) (Fig. 3g), but not the effects of flooding $(\mathrm{z}=1.69, \mathrm{P}=0.090)$, amount of habitat $(\mathrm{z}=1.79, \mathrm{P}=0.073)$ and the habitat descriptor $(\mathrm{z}$ $=1.57, \mathrm{P}=0.116)$.

The best GLMM explaining the species richness of mobile orthopterans included only the effect of landscape (Table 2), which was significant $(\mathrm{z}=2.14, \mathrm{P}=0.032)$ (Fig. 3e).

For sedentary species, the model selection procedure (Table 2) yielded a best model that only included the significant effect of amount of habitat $(\mathrm{z}=2.90, \mathrm{P}=0.004)$ (Fig. 3c).

The average best model for xerophilous species included the effects of landscape and the habitat descriptor (Table 2 ), with the difference associated with landscape significant $(\mathrm{z}=2.10, \mathrm{P}=0.036)$ (Fig. $3 \mathrm{~h})$ but not that associated with the habitat descriptor $(\mathrm{z}=1.42, \mathrm{P}=0.156)$.

For non-xerophilous orthopterans the model selection (Table 2) resulted in an average best model that included the effects of the amount of habitat, the habitat descriptor, flooding and landscape. Only the effect of the landscape was not significant $(\mathrm{z}=1.26, \mathrm{P}=0.206)$, but that associated with the percentage of grassland $(\mathrm{z}=2.18, \mathrm{P}=0.029)$ (Fig. $2 \mathrm{~d})$, the habitat descriptor $(\mathrm{z}=2.29, \mathrm{P}=0.022)$ (Fig. $2 \mathrm{f}$ ) and flooding $(\mathrm{z}=2.25, \mathrm{P}=0.024)$ (Fig. 2i) were significant.

\section{DISCUSSION}

\section{Effects of landscape features and spatial scale}

Based on the scale-dependent effect of the composition of the landscape recorded in the present study, the percent-

Table 2. The GLMM components included in the average best models explaining the species richness of the different trait groups of Orthoptera. Abbreviations of explanatory variables and factors: homogeneous vs. heterogeneous landscape (Landscape), flooded vs. non-flooded sites (Flooding), percentage of grassland within in a radius of $500 \mathrm{~m}$ of the site sampled (Habitat amount), scores of the first PCA axis as habitat descriptor (Habitat).

\begin{tabular}{|c|c|c|c|c|c|c|}
\hline Trait groups & Model components & d.f. & logLik & $\mathrm{AICc}$ & Delta & Weight \\
\hline \multirow{3}{*}{ All species } & Habitat amount & 3 & -49.32 & 105.84 & 0 & 0.48 \\
\hline & Landscape + Habitat amount & 4 & -48.43 & 106.97 & 1.12 & 0.27 \\
\hline & Flooding + Habitat amount & 4 & -48.52 & 107.15 & 1.31 & 0.25 \\
\hline \multirow{2}{*}{ Ensifera species } & Habitat amount & 3 & -36.91 & 87.02 & 0 & 0.61 \\
\hline & Habitat & 3 & -40.70 & 88.59 & 1.57 & 0.39 \\
\hline \multirow{4}{*}{ Caelifera species } & Habitat amount + Landscape & 4 & -44.98 & 100.07 & 0 & 0.31 \\
\hline & Landscape & 3 & -46.64 & 100.49 & 0.42 & 0.25 \\
\hline & Flooding + Landscape & 4 & -45.20 & 100.50 & 0.43 & 0.25 \\
\hline & Habitat + Landscape & 4 & -45.41 & 100.93 & 0.87 & 0.20 \\
\hline Mobile species & Landscape & - & - & - & - & - \\
\hline Sedentary species & Habitat amount & - & - & - & - & - \\
\hline \multirow{3}{*}{ Xerophilous species } & Landscape & 3 & -45.03 & 97.26 & 0 & 0.43 \\
\hline & Landscape + Habitat & 4 & -44.10 & 98.30 & 1.04 & 0.19 \\
\hline & Null & 2 & -46.98 & 98.53 & 1.27 & 0.17 \\
\hline \multirow{4}{*}{ Non-xerophilous species } & Habitat amount & 3 & -36.87 & 80.94 & 0 & 0.29 \\
\hline & Habitat & 3 & -36.89 & 80.98 & 0.04 & 0.28 \\
\hline & Flooding & 3 & -36.89 & 80.99 & 0.05 & 0.28 \\
\hline & Flooding + Landscape & 4 & -36.08 & 82.27 & 1.33 & 0.15 \\
\hline
\end{tabular}


a)

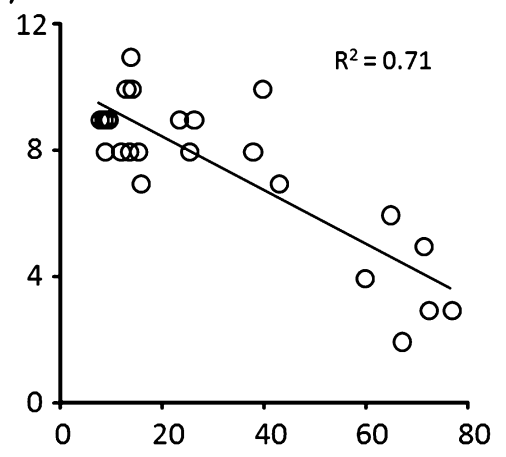

b)

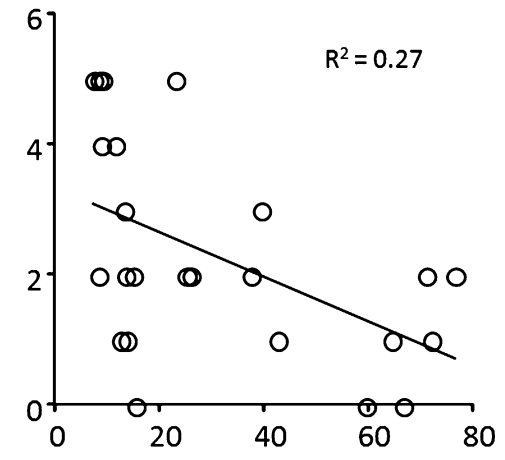

c)

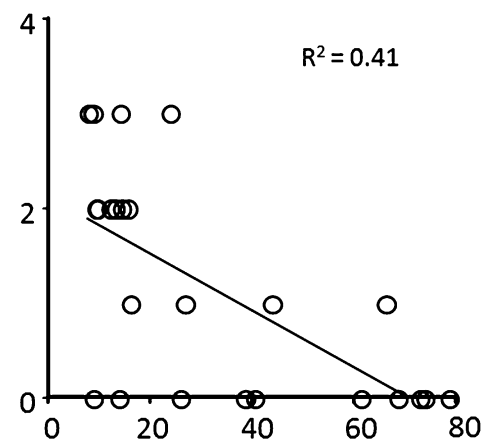

Grassland amount (\%)

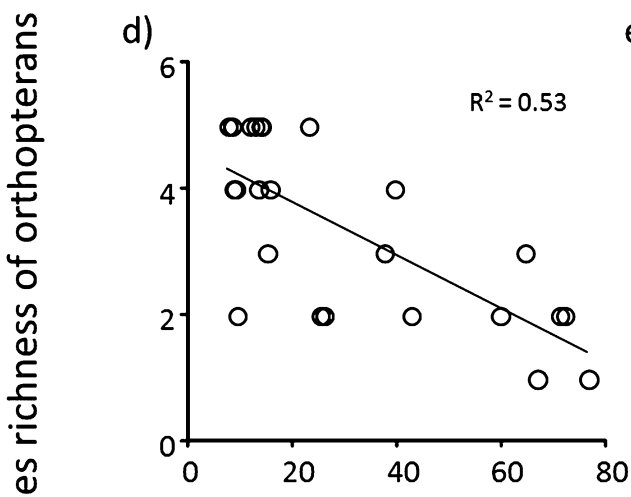

e)

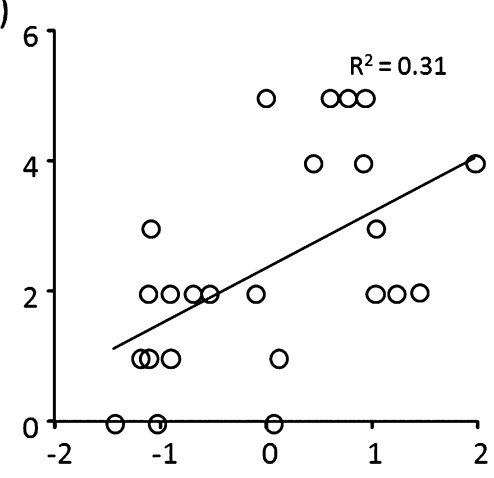

f)

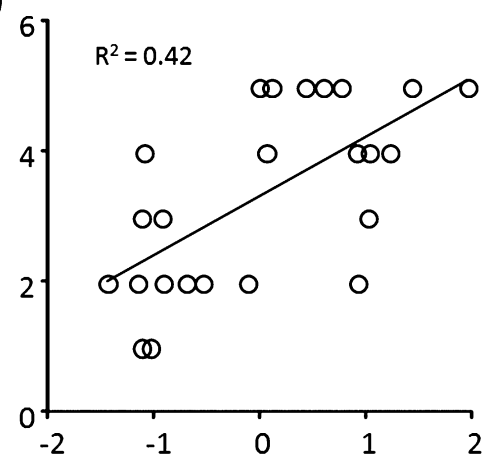

Grassland amount (\%)

Habitat descriptor (scores of axis 1)

g)

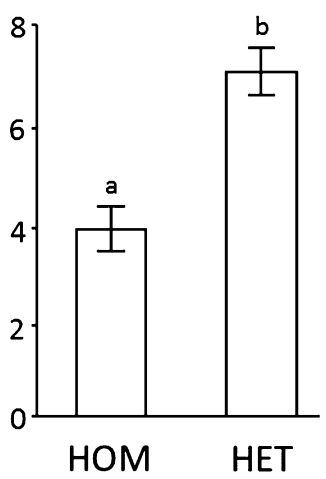

h)

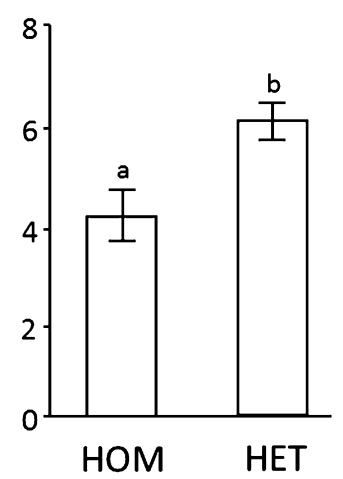

i)

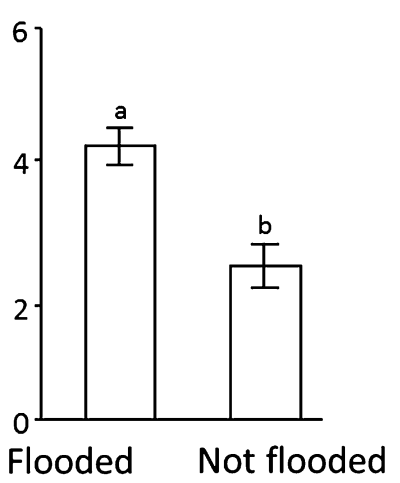

Fig. 3. The significant effects of flooding, habitat characteristics and landscape variables on the species richness of different life-history trait groups of Orthoptera delineated using model selection of GLMM. The effects of the explanatory factors and variables were averaged across the best models with delta $<2$. Scatter plots show the relations between the percentage of grassland in the surroundings and the total species richness (a), the species richness of Ensifera (b), sedentary (c) and non-xerophilous (d) orthopterans; the relationship between the habitat descriptor and the species richness of Ensifera (e) and non-xerophilous (f) orthopterans. Bar charts represent the differences in the species richness of Caelifera $(\mathrm{g})$ and mobile orthopterans $(\mathrm{h})$ in the two landscapes; the differences in the species richness of non-xerophilous species (i) at flooded and non-flooded sites. For significances see the results of the model averaging cited in the text.

age of grassland in the surroundings explained the majority of the variability in orthopteran species richness within a radius of $500 \mathrm{~m}$; this scale has been shown to be relevant in terms of the spatial effects for several arthropod groups (e.g. Schmidt \& Tscharntke, 2005; Öberg et al., 2007; Torma \& Császár 2013; Torma et al., 2014). With an increase in the percentage of the area covered by grassland, the species richness of orthopterans decreased, which is contrary to the prediction of the habitat amount hypothesis
(Fahrig, 2013). However, Fahrig (2013) emphasized that the amount of habitat can be a good predictor for species richness, but is only part of the effect of the surrounding landscape. The studies (e.g. Marini et al., 2008, 2009a, 2010; Badenhausser \& Cordeau, 2012) that report a negative relationship between the proportion of grassland in the surrounding area and Orthopteran species richness emphasize the importance of ecotones. These papers suggest that contrary to the expectation based on the higher mortality of 
Orthoptera in large mown grasslands, in a landscape with a relatively low amount of grasslands, the local Orthoptera diversity can benefit from the presence of ecotonal habitats due to what are referred to as rescue effects.

In a previous study, Torma \& Császár (2013) show that different landscapes along the lower reaches of TRB host similar assemblages of Heteroptera. Contrary to this, assemblages of Orthoptera in the present study differed in their species composition in the two landscapes, despite sampling similar habitats. Similar to other studies (e.g. Torma et al., 2014) we suggest that different insect groups responded differently to habitat and landscape features, and orthopterans are more affected by landscape features than habitat characteristics in this region. This suggestion is corroborated by the significant positive association between the heterogeneous landscape and species richness of many trait groups recorded in this study. Presumably, in a more heterogeneous landscape, a grassland patch is likely to be colonized by more species from ecotonal habitats as it provides suitable conditions for foraging and reproduction (Marini et al., 2008).

\section{Effect of habitat characteristics}

Surprisingly, habitat characteristics affected only the species richness of Ensifera and non-xerophilous species. Non-xerophilous species obviously preferred sites with moist soil and thus more dense vegetation. Species of Ensifera also responded to the habitat characteristics of the sites as they preferred moist sites with more complex vegetation. The importance of humidity for egg and larval development of orthopterans is emphasized in several studies (e.g. Hodek, 2003; Wünsch et al., 2012), and Ensifera generally need more water for egg development than Acrididae (Ingrisch \& Köhler, 1998). Differences between Caelifera and Ensifera with regard to vegetation characteristics are also reported by e.g. Marini et al. (2009b), who suggest that Caelifera, unlike Ensifer, prefer regularly mown, less dense vegetation.

\section{Effect of flooding}

Flooding is considered to be a major disturbance for invertebrate assemblages in riparian habitats (Foeckler et al., 2006). Although the dispersal ability of species is important for the structuring of invertebrate assemblages in flooded habitats (Rothenbücher\& Schaefer, 2006; Lambeets et al., 2009) before and after flooding (Rothenbücher $\&$ Schaefer, 2006), we did not find any significant effect of flooding on the different mobility trait groups. Instead of active dispersal, Dziock et al. (2011) emphasize the importance of passive dispersal ability of orthopterans in floodplains. Certain orthopterans lay eggs in plants or under tree bark and their eggs can be transported together with their substrates by water. This potentially enables these species to colonise even remote areas; however a larger number of offspring (eggs) is needed, because a large proportion of them are likely to end up in unfavourable habitats. Compared to Caelifera, Ensifera species are usually more dependent on passive dispersal and have more ovarioles, but we did not find any significant effect of flooding on Ensifera species richness.

However, our results are hard to generalize as the structure and composition of animal assemblages can change rapidly in riparian areas that are frequently flooded (Lambeets et al., 2009). Presumably, the results of a study following severe flooding would reveal a stronger and more consistent effect of flooding.

\section{Implication for conservation}

As their diversity is currently declining in many temperate regions, assemblages of Orthoptera are the focus of numerous conservation studies. In fact, more than half of the orthopteran species are endangered in Europe (Ingrisch \& Köhler, 1998; Reinhardt et al., 2005). The present study was carried out in habitats of low natural value compared to Natura 2000 and other protected areas in Hungary, despite the occurrence of G. glabra and R. nitidula, which are endangered or critically endangered in surrounding countries (Berg \& Zuna-Kratky, 1997; Maas et al., 2002; Krištin et al., 2007; Liana, 2007) and P. vittata, which is close to extinction along the edge of the Pannonian Region (Holusa et al., 2012). These facts confirm that the habitats in the TRB can serve to maintain high orthopteran (and presumably other invertebrate) diversity in the Pannonian Region. We agree with Hernández-Manrique et al. (2012), who conclude that existing conservation strategies, which are based mainly on the protection of certain areas, often selected based on the presence there of particular plant and vertebrate species, may be insufficient for ensuring the conservation of invertebrate species. Therefore, we emphasize that even in countries where considerable areas of high natural value grassland still exist, non-protected meadows, strip-like grassy habitats such as dikes, ditch banks, road verges should receive more attention and should be given a major role in the conservation of invertebrate diversity.

ACKNOWLEDGEMENTS. We are grateful to the anonymous reviewers and the associate editor M. Konvička for useful comments on an earlier version of the manuscript, and we also thank C. Tölgyesi for his suggestions on linguistic issues.

\section{REFERENCES}

Badenhausser I. \& Cordeau S. 2012: Sown grass strip - a stable habitat for grasshoppers (Orthoptera: Acrididae) in dynamic agricultural landscapes. - Agric. Ecosyst. Environ. 159: 105111.

BARTOŃ K. 2013: MuMIn: Multi-Model Inference. R Package Version 1.9.13. http://CRAN.R-project.org/package=MuMIn Accessed 19 March 2014.

Batáry P., Orci K.M., Báldi A., Kleijn D., Kisbenedek T. \& ERDös S. 2007: Effects of local and landscape scale and cattle grazing intensity on Orthoptera assemblages of the Hungarian Great Plain. - Basic Appl. Ecol. 8: 280-290.

Bates D., Maechler M., Bolker B. \& Walker S. 2013: lme4: Linear Mixed-Effects Models Using Eigen and S4. R Package Version 1.0-5. http://CRAN.R- project.org/package=lme4 Accessed 19 March 2014.

Bauer N. \& KenYeres Z. 2007: Seasonal changes of microclimatic conditions in grasslands and its influence on orthopteran assemblages. - Biologia 62: 742-748. 
Berg H.-M. \& ZunA-KratKy T. 1997: Rote Listen ausgewählter Tiergruppen Niederösterreichs. Heuschrecken und Fangschrecken (Insecta: Saltatoria, Mantodea). Landesregierung, Wien, 112 pp.

Cozzi G., Müller C.B. \& Krauss J. 2008: How do local habitat management and landscape structure at different spatial scale affect fritillary butterfly distribution on fragmented wetlands? —Landsc. Ecol. 23: 269-283.

DEÁK J.Á. 2007: 200 years of habitat changes and landscape use in the South-Tisza-valley, Hungary. In Okruszko et al. (eds): Wetlands: Monitoring, Modelling and Management. Taylor and Francis Group, London, pp. 45-54.

Dziock F., Gerisch M., Siegert M., Hering I., Scholz M. \& Ernst R. 2011: Reproducing or dispersing? Using trait based habitat templet models to analyse Orthoptera response to flooding and land use. - Agric. Ecosyst. Environ. 145: 85-94.

ENDo C. 2006: Seasonal wing dimorphism and life cycle of the mole cricket Gryllotalpa orientalis (Orthoptera: Gryllotalpidae). - Eur. J. Entomol. 103: 743-750.

FAHRIG L. 2013: Rethinking patch size and isolation effects: the habitat amount hypothesis. - J. Biogeogr. 40: 1649-1663.

Fartmann T., Krämer B., Stelzner F. \& Poniatowski D. 2012 Orthoptera as ecological indicators for succession in steppe grassland. - Ecol. Ind. 20: 337-344.

Foeckler F., Deichner O., Schmidt H. \& Castella E. 2006: Suitability of molluscs as bioindicators for meadow- and floodchannels of the Elbe-floodplains. - Int. Rev. Hydrobiol. 91: 314-325.

GALlÉ L. (ed.) 2005: Vegetation and Fauna of Tisza River Basin I. Tiscia Monograph Series 7, Tisza Research Group of the HAS and University of Szeged, Szeged, 197 pp.

Gallé L. (ed.) 2008: Vegetation and Fauna of Tisza River Basin II. Tiscia Monograph Series 8, Tisza Research Group of the HAS and University of Szeged, Szeged, $132 \mathrm{pp}$.

Gallé L., Margóczi K., KovÁcs É., GyÖrffy G., Körmöczi L. \& NÉmeth L. 1995: River valleys: Are they ecological corridors? — Tiscia 29: 53-58.

Gallé R., Vesztergom N. \& Somogyi T. 2011: Environmental conditions affecting spiders in grasslands at the lower reach of the River Tisza in Hungary. - Entomol. Fenn. 22: 29-38.

GARDINER T. \& Dover J. 2008: Is microclimate important for Orthoptera in open landscapes? - J. Insect Conserv. 12: 705709 .

Godreau V., Bornette G., Frochot B., Amoros C., Castella E., Oerli B., Chambaud F., Oberti D. \& Craney E. 1999: Biodiversity in the floodplain of Saône: a global approach. — Biodiv. Conserv. 8: 839-864.

Gregory D.M., Swanson F.J., McKee W.A. \& Cummins K. 1991: An ecosystem perspective of riparian zones. - Bioscience 41: $540-551$

Grueber C.E., Nakagawa S., Laws R.J. \& Jamieson I.G. 2011: Multimodel inference in ecology and evolution: challenges and solutions. - J. Evol. Biol. 24: 699-711.

Hernández-Manrique O.L., Numa C., Verdú J.R., Galante E. \& Loво J.M. 2012: Current protected sites do not allow the representation of endangered invertebrates: the Spanish case. - Insect Conserv. Div. 5: 414-421.

Hodek I. 2003: Role of water and moisture in diapause development (A review). - Eur. J. Entomol. 100: 223-232.

Holusa J., Kocarek P., Marhoul P. \& Skokanova H. 2012: Platycleis vittata (Orthoptera: Tettigoniidae) in the northwestern part of its range is close to extinction: is this the result of landscape changes? - J. Insect Conserv. 16: 295-303.

IngRISCH S. \& KöHLER G. 1998: Die Heuschrecken Mitteleuropas. Westarp Wissenschaften, Magdeburg, 460 pp.
Kotiaho J.S., Kaitala V., Komonen A. \& Pärvinen J. 2005: Predicting the risk of extinction from shared ecological characteristics. - Proc. Natl. Acad. Sci. 102: 1963-1967.

KrIŠtin A., KaŇUch P. \& SÁROSSY M. 2007: Distribution and ecology of Ruspolia nitidula (Scopoli 1786) and Aiolopus thalassinus (Fabricius 1781) (Orthoptera) in Slovakia. - Linzer Biol. Beitr. 39: 451-461.

Lambeets K., Vandegehuchte M.L., Maelfait J-P. \& Bonte D. 2009: Integrating environmental conditions and functional life history traits for riparian arthropod conservation planning. Biol. Conserv. 146: 625-637.

LianA A. 2007: Gampsocleis glabra (Herbst, 1786), Stepówka, Heath Bush-cricket. In: Głowaciński, Z. \& Nowacki, J.(eds.): Polish Red Data Book of Animals - Invertebrates. Institute of Nature Conservation PAS, Kraków, 448 pp..

MaAs S., Detzel P. \& Staudt A. 2002: Gefährdungsanalyse der Heuschrecken Deutschlands. Verbreitungsatlas, Gefährdungseinstufung und Schutzkonzepte. Bundesamt für Naturschutz, Bonn-Bad Godesberg.

Marini L., Fontana P., Scotton M. \& KlimeK S. 2008: Vascular plant and Orthoptera diversity in relation to grassland management and landscape composition in the European Alps. - $J$. Appl. Ecol. 45: 361-370.

Marini L., Fontana P., Battisti A. \& Gaston K.J. 2009a: Agricultural management, vegetation traits and landscape drive orthopteran and butterfly diversity in a grassland-forest mosaic: a multi-scale approach. — Insect Conserv. Div. 2: 213-220.

Marini L., Fontana P., Battisti A. \& Gaston K.J. 2009b: Response of orthopteran diversity to abandonment of semi-natural meadows. - Agric. Ecosyst. Environ. 132: 232-236.

Marini L., Bonmarco R., Fontana P. \& Battisti A. 2010: Disentangling effects of habitat diversity and area on orthopteran species with contrasting mobility. - Biol. Conserv. 143: 2164-2171.

Marini L., ÖCkinger E., Battisti A. \& Bommarco R. 2012: High mobility reduces beta-diversity among orthopteran communities - implications for conservation. - Insect Conserv. Div. 5: $37-45$.

Münsch T., Fartmann T., Machalett B. \& Poniatowski D. 2013: The pygmy mole cricket Xya variegata as an indicator for dynamic river systems. - J. Insect Conserv. 17: 521-528.

Naiman R.J., Décamps H. \& McClain M.E. 2005: Riparia: Ecology, Conservation, and management of 705 streamside communities. Elsevier Academic Press Inc.

Öвеrg S., Еквом B. \& Bommarco R. 2007: Influence of habitat type and surrounding landscape on spider diversity in Swdish agroecosystems. - Agric. Ecosyst. Environ. 122: 211-219.

Oksanen J., Blanchet F.G., Kindt R., Legendre P., Minchin P.R., O'Hara R.B., Simpson G.L., Solymos P., Stevens M.H.H. \& Wagner H. 2013: Vegan: Community Ecology Package. 2.010. $<$ http://CRAN.R-project.org/package= $=$ egan $>19$ March 2014.

Poniatowski D \& Fartmann T. 2008: The classification of insect communities: Lessons from Orthoptera assemblages of semidry calcareous grasslands in central Germany. - Eur. J. Entomol. 105: 659-671.

PONIATOWSKI D. \& FARTMANN T. 2009: Experimental evidence for density-determined wing dimorphism in two bush-crickets (Ensifera: Tettigoniidae) - Eur. J. Entomol. 106: 599-605.

Poniatowski D. \& FARTMANN T. 2010: What determines the distribution of a flightless bush-cricket (Metrioptera brachyptera) in a fragmented landscape? - J. Insect Conserv. 14: 637-645.

Poniatowski D. \& FARTMANN T. 2011: Weather-driven changes in population density determine wing dimorphism in a bushcricket species. - Agric. Ecosyst. Environ. 145: 5-9. 
RÁDAI Ö. (ed.) 1995: River Corridors in Hungary: A Strategy for the Conservation of the Danube and its Tributaries (19931994). IUCN, Gland Switzerland and Budapest, $124 \mathrm{pp}$.

R Core Team 2013: R: A Language and Environment for Statistical Computing. R Foundation for Statistical Computing, Vienna, Austria. http://www.R-project.org, Accessed 19 March 2014.

Reinhardt K., Köhler G., Maas S. \& Detzel P. 2005: Low dispersal ability and habitat specificity promote extinctions in rare but not in widespread species: the Orthoptera of Germany. Ecography 28: 593-602.

RothenbÜCHer J. \& SCHAEFer M. 2006: Submersion tolerance in floodplain arthropod communities. - Basic Appl. Ecol. 7: $398-408$.

SChMidT M.H. \& TscharntKe T. 2005: Landscape context of sheetweb spider (Araneae: Linyphiidae) abundance in cereal fields. - J. Biogeogr. 32: 467-473.

Sendzimir J., Magnuszewsiki P., Flachner Z., Balogh P., Molnár G., SÁrVÁri A. \& NAGY Z. 2008: Assessing the resilience of a river management regime: Informal learning in a shadow network in the Tisza River Basin. - Ecol. Soc. 13: 11.

Sommerwerk N., Hein T., Schneider-Jakoby M., Baumgartner C., Ostojić A., Paunović M., Bloesch J., Siber R. \& Tockner K. 2009: The Danube river basin. In Tockner K., Uehlinger U. \& Robinson C.T. (eds): Rivers of Europe. Elsevier, Amsterdam, pp. 59-112.

Steffan-Dewenter I., Münzenberg U., Bürger C., Thies C. \& TsCHARNTKE T. 2002: Scale-dependent effects of landscape context on three pollinator guilds. - Ecology 83: 1421-1432.
Tockner K., Uehlinger U., Robinson C.T., Tonolla D., Siber R. \& Peter F.D. 2009: Introduction of European rivers. In Tockner K., Uehlinger U. \& Robinson C.T. (eds): Rivers of Europe. Elsevier, Amsterdam, pp. 1-22.

Torma A. \& Cś́szár P. 2013: Species richness and composition patterns across trophic levels of true bugs (Heteroptera) in the agricultural landscape of the lower reach of the Tisza River Basin. - J. Insect Conserv. 17: 35-51.

Torma A., Gallé R. \& Bozsó M. 2014: Effects of habitat and landscape characteristics on the arthropod assemblages (Araneae, Orthoptera, Heteroptera) of sand grassland remnants in southern Hungary. - Agric. Ecosyst. Environ. 196: 42-50.

Ward J.V., Tockner K. \& Schiemer F. 1999: Biodiversity of floodplain river ecosystems: ecotones and connectivity. Reg. Riv. Res. Manag. 15: 125-139.

Willott S.J. \& Hassall M. 1998: Life-history responses of British grasshoppers (Orthoptera: Acrididae) to temperature change. - Funct. Ecol. 12: 232-241.

WünsCh Y., SChIRMEL J. \& FARTMANN T. 2012: Conservation management of coastal dunes for Orthoptera has to consider oviposition and nymphal preferences. - J. Insect Conserv. 16: 501-510.

ZwICK P. 1992: Stream habitat fragmentation - a threat to biodiversity. - Biodiv. Conserv. 1: 80-97.

Received November 4, 2014; revised and accepted September 24, 2015 Published online January 11, 2016 


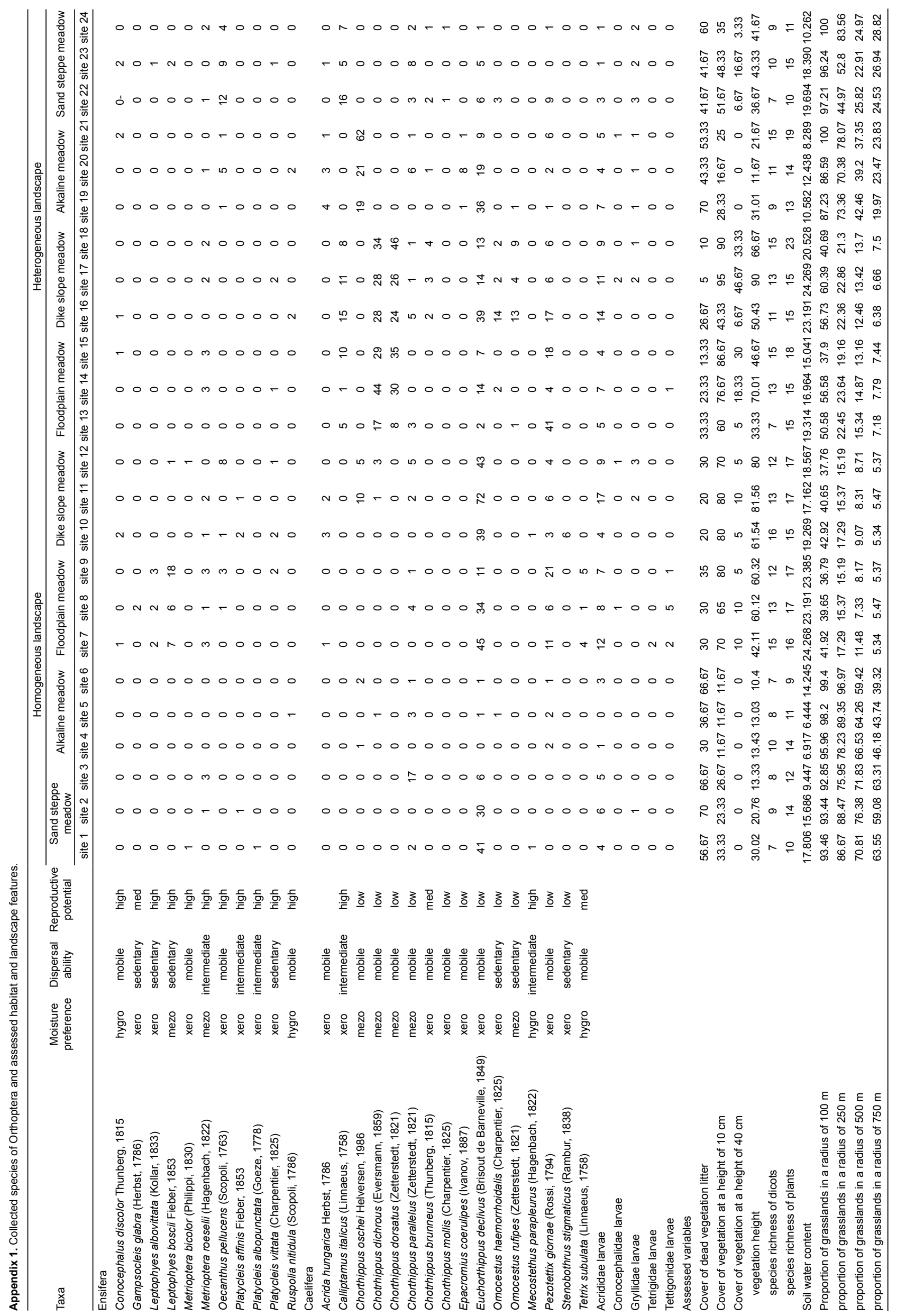


Appendix 2. Correlation matrix of habitat variables (above: $p$-values, below: correlation coefficients). Abbreviations: cover of dead vegetation litter (litter), total cover of vegetation at a height of $10 \mathrm{~cm}$ (veg.cover10), total cover of vegetation at a height of $40 \mathrm{~cm}$ (veg.cover40), average height of the vegetation (veg.height), species richness of all plants (all plants), species richness of only dicotyledonous plants (dicots), soil water content (moisture) and habitat descriptor (axis 1).

\begin{tabular}{|c|c|c|c|c|c|c|c|c|}
\hline & litter & veg.cover10 & veg.cover40 & veg.height & all plants & dicots & moisture & axis 1 \\
\hline litter & & $<0.001$ & $<0.001$ & $<0.001$ & 0.001 & 0.002 & 0.010 & $<0.001$ \\
\hline veg.cover10 & -0.778 & & $<0.001$ & $<0.001$ & 0.001 & 0.001 & $<0.001$ & $<0.001$ \\
\hline veg.cover40 & -0.722 & 0.744 & & $<0.001$ & 0.012 & 0.013 & 0.015 & $<0.001$ \\
\hline veg.height & -0.711 & 0.893 & 0.659 & & 0.003 & 0.008 & $<0.001$ & $<0.001$ \\
\hline all plants & -0.655 & 0.653 & 0.502 & 0.576 & & $<0.001$ & 0.112 & $<0.001$ \\
\hline dicots & -0.606 & 0.619 & 0.499 & 0.530 & 0.803 & & 0.108 & 0.001 \\
\hline moisture & -0.515 & 0.733 & 0.489 & 0.676 & 0.333 & 0.336 & & $<0.001$ \\
\hline axis 1 & -0.852 & 0.977 & 0.784 & 0.943 & 0.667 & 0.626 & 0.714 & \\
\hline
\end{tabular}

